УДК 616.24-002-07:616-073.756.

DOI 10.11603/bmbr.2706-6290.2021.1.11821

В. В. Палапа', В. М. Оксюта', О. П. Мялюк', П. П. Семенюк²

КЗВО «Рівненська медична академія» Рівненської обласної ради ${ }^{1}$

Рівненський обласний клінічний лікувально-діагностичний иентр імені В. Полішука

\title{
КОМП’ЮТЕРНА ТОМОГРАФІЯ ЯК МЕТОД ПРОГНОЗУВАННЯ РОЗВИТКУ COVID-19
}

\section{Комп'ютерна томографрія як метод прогнозування розвитку COVID-19}

\section{В. В. Палапа ${ }^{1}$, В. М. Оксюта ${ }^{1}$, О. П. Мялюк ${ }^{1}$,} П. П. Семенюк ${ }^{2}$

КЗВО «Рівненська медична академія» Рівненської обласної ради

Рівненський обласний клінічний лікувально-

діагностичний центр імені В. Поліщука²

Резюме. Національна комісія з питань охорони здоров'я Китаю дійшла висновку, що найбільш вразливою верствою населення є саме пацієнти похилого віку із коморбідною патологією. У хворих найчастішим ускладненням коронавірусної хвороби визнане ураження легеневої тканини, яке сьогодні трактується як «негоспітальна пневмонія». На жаль, незважаючи на існування найсучасніших методів ідентиярікації різних патогенних мікроорганізмів, приблизно в половині випадків збудник пневмонії, у тому числі й негоспітальної, не виявляється. Тому для діагностики вірусасоційованої пневмонії особливого значення набуває такий метод як комп'ютерна томографрія.

Мета дослідження - проаналізувати дані комп'ютерної томографрії як методу візуалізації змін та контролю динаміки розвитку ураження легеневої тканини у хворих на вірусасоційовану пневмонію.

Матеріали і методи. Обстежено 48 пацієнтів із підозрою на вірусну пневмонію за допомогою комп'ютерного томографра марки GE OPTINA CT 520 (2017 р. випуску). Стать не брали до уваги, вік 40-75 років. Протокол обстеження: $120 \mathrm{kV}, 350 \mathrm{~mA}$, крок $5 \mathrm{~mm}$. Реконструкція: Lung - $1.25 \mathrm{~mm}$ (товщина), STD - $0.625 \mathrm{~mm}$ (товщина).

Результати. Проведено порівняльну оцінку клінічних характеристик та особливостей візуалізації серед учасників двох груп, які відрізнялися за тяжкістю перебігу: середньої тяжкості (перша група) і тяжкого перебігу (друга група). Відповідно, серед пацієнтів, які увійшли до першої групи, переважали особи віком 4060 років (74,2\%), значна частина яких скаржилась на лихоманку (78,2 \%), задишку (67,6 \%) та загальну слабість (80,2 \%) як первинні прояви захворювання. I тільки у 9 (18,7\%) осіб розвиток патології був пов'язаний з інфекційним спалахом у певному середовищі. В усіх пацієнтів, у яких захворювання перебігало з вираженою тяжкістю, належали до старших вікових груп. У

\section{Computed tomography as a metod of predicting the development of COVID-19}

V. V. Palapa ${ }^{1}$, V. M. Oksyuta ${ }^{1}$, O. P. Mialiuk ${ }^{1}$, P. P. Semenyuk ${ }^{2}$

Municipal Institution of Higher Education "Rivne Medical Academy" Rivne Regional Council ${ }^{1}$

Rivne Regional Clinical Medical and Diagnostic Center named after V. Polishchuk ${ }^{2}$

e-mail: vpalapa@ukr.net

Summary. The National Health Commission of China has concluded that the most vulnerable are elderly patients with comorbid conditions. The most common complication of coronavirus disease in patients is lung damage, which is now treated as "community-acquired pneumonia" (CAP). Despite the existence of modern methods of identification of various pathogenic microorganisms, in about half of the cases the causative agent of pneumonia, including community-acquired, is not detected. Therefore, for the diagnosis of associated pneumonia virus, a method such as computed tomography is of particular importance.

The aim of the study - analysis of computed tomography data as a method of visualization of changes and control of the dynamics of lung tissue damage in patients with virus-associated pneumonia.

Materials and Methods. We assessed 48 patients with suspected viral pneumonia using a GE OPTINA CT 520 computed tomography (2017). Gender was not taken into account, age 40-75 years. Examination protocol: $120 \mathrm{kV}$, $350 \mathrm{~mA}$, step 5mm. Reconstruction: Lung - $1.25 \mathrm{~mm}$ (thickness), STD - $0.625 \mathrm{~mm}$ (thickness).

Results. We conducted a comparative assessment of clinical characteristics and features of imaging among participants in two groups, which differed in severity: moderate (group 1) and severe (group 2). Accordingly, among patients included in group 1 , the predominant age was 40-60 years (74.2\%), a significant proportion of whom complained of fever (78.2\%), shortness of breath (67.6\%) and general weakness (80.2\%) as the primary manifestations of the disease. And only in 9 (18.7\%) people the development of pathology was associated with an infectious outbreak in a certain environment. All patients with severe disease belonged to the older age groups. In general, in the analysis of tomogram parameters, such as distorted lung pattern, the presence of bronchiecta- 
загальному при аналізі таких показників томограми, як спотворений легеневий малюнок, наявність бронхоектазів та випоту в плевральній порожнині, які можуть свідчити на користь вірусного ураження, статистично відрізнялись у пацієнтів зазначених груп порівняння.

Висновки. Встановлено, що комп'ютерна томографрія є ефрективним інструментальним методом діагностики вірусного ураження легеневої тканини. Рекомендовано використовувати комп'ютерну томографрію як найкращий метод візуалізації розвитку, обсягу ураження та динаміки змін вірусасоційованої пневмонії.

Ключові слова: комп'ютерна томографрія; вірусасоційована пневмонія; COVID-19.

\section{ВСТУП}

Спалах хвороби, викликаний новим коронавірусом 2019 nCoV, розпочався в середині грудня 2019 р. у місті Ухань провінції Хубей Центрального Китаю з перших випадків пневмонії невідомого походження у місцевих жителів, пов'язаних із ринком тварин і продуктів Хуанань в Ухані. Згодом китайські вчені виділили новий коронавірус — 2019 nCoV, який не менше ніж на 70 \% схожий за генетичною послідовністю на вірус SARS-CoV, що викликає тяжкий гострий респіраторний синдром (відомий також як атипова пневмонія). Потім встановили генетичну послідовність геному нового вірусу, який назвали COVID-19. Експерти дійшли висновку, що 2019 nCoV, мабуть, є гібридом коронавірусу, виявленого в кажанів, та іншого коронавірусу невідомого походження. На наступному етапі дослідники виявили, що вірус, ймовірно, передався людям від змій. Китайська влада офріційно підтвердила, що мали місце випадки передачі інорекції від людини до людини [1].

Коронавіруси (CoV) - велика родина вірусів, які спричиняють низку патологічних станів від легкої форми респіраторної інфрекції до тяжкого гострого респіраторного синдрому (ТГРС) [4]. Наразі відомо про сезонну циркуляцію в популяції чотирьох коронавірусів (HCoV-229E, -OC43, -NL63 та -HKU1), які зумовлюють ураження дихальних шляхів легкого та середнього ступенів тяжкості [2].

Найтяжчі захворювання були пов'язані зі спалахами ТГРС (Severe Acute Respiratory Syndrome, SARS) у 2002-2003 рр. [3] і близькосхідного дихального синдрому (Middle East Respiratory Syndrome, MERS) у 2012 р. [2]. Клінічною особливістю SARS була швидкість, 3 якою розвивалися симптоми гострого респіраторного дистрес-синдрому (ГРДС) [2].

Спорадичне виникнення нових типів CoV і зумовлених ними спалахів нагадують, що віруси цього сімейства становлять серйозну глобальну загрозу для здоров'я населення планети. Дуже ймовірно, що у зв'язку зі змінами клімату, екології, sis and effusion in the pleural cavity, this may indicate in favor of viral lesions, statistically different in patients of these comparison groups.

Conclusions. Computed tomography has been shown to be an effective tool for diagnosing viral lung disease. It is recommended computed tomography to be used as the best method to visualize the development, extent and dynamics of associated changes in the pneumonia virus.

Key words: computed tomography; virus-associated pneumonia; COVID-19.

збільшенням взаємодії людини 3 тваринами нові спалахи цієї інфрекції неминучі [5].

Наприкінці січня 2020 р. Всесвітня організація охорони здоров'я (ВОО3) констатувала епідемію, а в березні, коли поширення захворювання набуло світового масштабу, охарактеризувала його як пандемію [6].

Більшість хворих має легкий перебіг із симптомами гострої респіраторної вірусної інфекції (ГРВІ) і може лікуватись в амбулаторних умовах, проте близько 15 \% - потребують госпіталізації, а 5 \% проведення різних видів респіраторної підтримки в умовах відділення інтенсивної терапії [7]. Серед пацієнтів із COVID-19 у США 19 \% були госпіталізовані в стаціонар, а 6 \% - у відділення інтенсивної терапії (BAIT).

Згідно з даними, високий ризик тяжкого перебігу захворювання притаманний людям старшого віку (65 років і більше), пацієнтам із закладів тривалого медичного перебування та особам із супутніми хронічними захворюваннями різних органів і систем [8].

Національна комісія з питань охорони здоров'я Китаю дійшла висновку, що найбільш вразливою верствою населення $є$ саме пацієнти похилого віку із коморбідною патологією, причому у 8,2 \% пацієнтів із COVID-19 має місце поєднання двох та більше хронічних захворювань. Серед супутньої патології у хворих із COVID-19 вікової групи 70 років та старше найчастіше реєструють метаболічні порушення та захворювання серцево-судинної системи. Крім того, рівень смертності у даного контингенту хворих є найвищим [9].

У хворих різних регіонів світу найчастішим ускладненням коронавірусної хвороби визнане ураження легеневої тканини, яке сьогодні трактується як «негоспітальна пневмонія», що $є$ одним із найбільш небезпечних та загрозливих для життя ускладнень.

Поширеність даної форми пневмонії на сьогодні $є$ дуже актуальною проблемою не тільки в Україні, а й в усьому світі, так як летальність при 
ній досить висока і майже не змінюється протягом останніх років [10].

Доведено існування більше ніж 100 видів збудників пневмонії, хоча лише декілька з них спричиняють більшість випадків. Найчастіше причиною негоспітальної пневмонії $€$ бактерії: пневмокок (у деяких регіонах - майже в 50 \% випадків), гемофрільна паличка (майже в 20 \% випадків), внутрішньоклітинні збудники (хламідія, мікоплазма, легіонела) (близько $20 \%$ випадків), золотистий стафілокок (до 5 \% випадків), грамнегативні бактерії (до 5 \% випадків) [11]. Приблизно в 15 \% хворих викликають різні віруси: вірус грипу, парагрипу, риносинцитіальний вірус, коронавіруси, метапневмовіруси тощо [12]. Ще рідше (не більше ніж у $5 \%$ випадків) етіологічними чинниками пневмонії можуть бути гриби (кандиди, пневмоциста) та найпростіші мікроорганізми.

На жаль, незважаючи на існування найсучасніших методів ідентиорікації різних патогенних мікроорганізмів (як бактеріальних, так і вірусних), приблизно в половині випадків збудник пневмонії, у тому числі й негоспітальної, не виявляється [11], тому лікарям часто доводиться орієнтуватись на клінічні й анамнестичні дані, результати лабораторних методів дослідження, рентгенологічні ознаки.

У зв'язку зі значним територіальним розповсюдженням вірусіндукованих інфекцій, у тому числі й COVID-19, що супроводжуються значним ураження легеневої тканини, які часто супроводжуються обтяженням патологічного процесу та, на жаль, невтішними результатами.

Тому для діагностики вірусасоційованої пневмонії особливого значення набуває такий метод ефрективної та ранньої візуалізації патологічних змін легеневої тканини, які характерні для уражень вірусної природи як інструментальний метод діагностики - комп'ютерна томографрія (КТ).

Метою дослідження було проаналізувати дані комп'ютерної томографії як методу візуалізації змін та контролю динаміки розвитку ураження легеневої тканини у хворих на вірусасоційовану пневмонію.

\section{МАТЕРІАЛИ І МЕТОДИ}

При проведенні дослідження було обстежено 48 пацієнтів із підозрою на вірусну пневмонію за допомогою комп'ютерного томографа марки GE OPTINA CT 520 (2017 р. випуску) в Рівненському обласному клінічному лікувально-діагностичному центрі ім. В. Поліщука. Стать не брали до уваги, вік 40-75 років. Дослідження виконано згідно 3 принципами Гельсінської декларації. Була отримана проінформована згода в усіх пацієнтів. Протокол обстеження: $120 \mathrm{kV}, 350 \mathrm{~mA}$, крок $5 \mathrm{~mm}$.
Реконструкція: Lung - 1.25 mm (товщина), STD $0.625 \mathrm{~mm}$ (товщина).

\section{РЕЗУЛЬТАТИ Й ОБГОВОРЕННЯ}

При обстеженні хворих на вірусасоційовану пневмонію за допомогою комп'ютерного томографа, методу, який може бути одним із перших досліджень, що демонструє ознаки вірусного ураження легень, дозволяє оцінити об'єм ураження та прогностичні ознаки розвитку процесу, було встановлено характерні закономірності зміни легеневої тканини у вигляді різних КТ-проявів.

Симптом «матового скла», як особливість зміни прозорості легеневої тканини, спостерігали у (86,7 \%) хворих, і це, на нашу думку, є передвісником у розвитку «респіраторного дистрес-синдрому». Ураження легень частіше було двостороннім (80,2 \%), супроводжувалось більш переореричним розпреділенням (82,1\%), з переважною локалізацією у задніх субплевральних (76,4 \%) та перибронхіальних $(80,1$ \%) відділах, та проявлялись мультивогнищевими проявами (54,5 \%) 3 переважним ураження нижніх відділів (55,5 \%). Елементи консолідації $(68,4$ \%) та розширення судин у ділянці ураження (74,3 \%) часто поєднувались із ділянками «матового скла». За допомогою комп'ютерної томографрії можна діагностувати не тільки характерні діагностичні ознаки вірусіндукованої пневмонії, але і ступінь ураження легеневої тканини. Якщо симптом «матове скло» зустрічається менше ніж у трьох місцях, свідчить про ураження легкого ступеня захворювання. Якщо даний симптом зустрічається 3 явищами консолідації, можна говорити про середню тяжкість перебігу захворювання, і якщо бувають ущільнення, - це свідчить про тяжкий перебіг.

При проведенні обстеження в різні періоди розвитку вірусної інфрекції спостерігалась певна стадійність процесу, орормування залишкових змін, характерних для вірусіндукованого ураження легеневої тканини, що в майбутньому може запускати процеси розвитку прогресуючого легеневого фріброзу.

У ході дослідження проаналізовано дані 48 пацієнтів із підозрою на вірусну пневмонію. Проведено порівняльну оцінку клінічних характеристик та особливостей візуалізації серед учасників двох груп, які відрізнялися за тяжкістю перебігу: середньої тяжкості (перша група) і тяжкого перебігу (друга група).

Відповідно серед пацієнтів, які увійшли до першої групи, переважали особи віком 40-60 років (74,2 \%), значна частина яких скаржились на лихоманку (78,2 \%), задишку $(67,6 \%)$ та загальну слабість (80,2 \%) як первинні прояви захворювання. І тільки у 9 (18,7 \%) осіб розвиток патології був пов'язаний з інфекційним спалахом у певному се- 
редовищі (сім'я, робота, відпочинок). До другої групи віднесли пацієнтів старших вікових груп, у яких симптоматика ускладнень була значно вищою: задишка (87,6 \%), висока температура тіла (92,2 \%), виражена слабість (97,0 \%).

У загальному при аналізі таких показників томограми як спотворений легеневий малюнок, наявність бронхоектазів та випоту в плевральній порожнині, які можуть свідчити на користь вірусного ураження, статистично відрізнялись у пацієнтів означених груп порівняння.

На нашу думку, ці порівняльні діагностичні критерії, могли б допомогти клініцистам ефективніше виявляти осіб із прогностично ускладненим перебігом захворювання.

Отже, можна допустити, що внаслідок проведеного аналізу комп'ютерних томограм, можна спростити визначення, оцінити стан та своєчасно розпочати відповідне лікування пацієнта з підоз-

\section{СПИСОК ЛІТЕРАТУРИ}

1. Чернишова Л. І. Коронавірусна інфекція / Л. І. Чернишова // «Актуальная инсректология». - 2020. - Т. 8, № 2. - С. 125-127.

2. Дзюблик І. В. Нові коронавіруси людини та захворювання органів дихання / І. В. Дзюблик, О. В. Кукало // Укр. пульмонол. журн. - 2015. - № 4. - С. 53-59.

3. Новая коронавирусная инфеекция (COVID-19): этиология, эпидемиология, клиника, диагностика, лечение и профилактика: учебно-методическое пособие / В. В. Никифоров, Л. В. Колобухина, С. В. Сметанина [и др.] // Департамент здравоохранения Москвы. - 2020. № 21. - C. 66-71 C.

4. Liang T. Handbook of COVID-19 prevention and treatment / T. Liang // Zhejiang University School of Medicine. - 2020. - No. 1 - P. 68.

5. Yuen K. S. SARS-CoV-2 and COVID-19: the most important research questions / K. S. Yuen, Z. W. Ye, S. Y Fung, C. P. Chan, D. Y. Jin // Cell Biosci. - 2020. No. 10. - P. 40

6. Callaway E. Why snakes probably aren't spreading the new China virus: one genetic analysis suggests reptilian reservoir - but researchers doubt that the coronavirus could have originated in animals other than birds or mammals / E. Callaway, D. Cyranoski // Nature. - 2020. - DOI: 10.1038/ d41586-020- 00180-8.

\section{REFERENCES}

1. Chernyshova LI. [Coronavirus infection]. Aktual infekt. 2020;8(2):125-7. Ukrainian.

2. Dzyublyk IV, Kukalo OV. [New human coronaviruses and respiratory diseases]. Ukr pulmonol zhurn. 2015;4: 539. Ukrainian.

3. Nikiforov VV, Kolobukhina LV, Smetanina SV, Mazankova LM, Plavunov NF, Shhelkanov NYu et al. New coronavirus infection (COVID-19): ethiology, epidemiology, clinic, diagnostics, treatment and prevention: teaching aid. [Новая коронавирусная иноекция (COVID-19): рою на вірусне (у тому числі й COVID-19) ураження легеневої тканини

\section{висновки}

У результаті дослідження можна зробити висновок, що проведення комп'ютерної томографії, яка $€$ високочутливим і високоспецифічним методом діагностики вірусної пневмонії, особливо пацієнтам з вираженими клінічними симптомами (лихоманка, дихальна недостатність, загальна слабість), та при відсутності аускультативної картини, рентгенологічних ознак, характерних для цього типу пневмонії, дозволить вчасно поставити діагноз, встановити ступінь розповсюдження патологічного процесу, визначитись лікуючому лікарю з необхідністю госпіталізації пацієнта, призначити патогенетичне лікування, що, у свою чергу, неодмінно вплине на ефективність лікування та зменшить різного роду ускладнень.

7. Clinical course and risk factors for mortality of adult inpatients with COVID-19 in Wuhan, China: a retrospective cohort study / Fei Zhou, Ting Yu, Ronghui Du, Guohui Fan [et al.] // Lancet. - 2020. - No. 395. - P.1054-1062.

8. Morley J. E. COVID-19 and older adult / J. E. Morley, B. Vellas // J. Nutr. Health Aging. - 2020. - DOI:10.1007/ s12603- 020-1349-9.

9. Sun P. Clinical characteristics of 50466 hospitalized patients with 2019-nCoV infection / Pengfei Sun, Shuyan Qie, Zongjian Liu [et al.] // J. Med. Virol. - 2020. DOI:10.1002/jmv.25735.

10. Joshua P. Metlay. Treatment of community-acquired pneumonia during the coronavirus disease 2019 (COVID-19) / P. Metlay Joshua, W. Waterer Grant // Pandemic. Ideas and Opinions. - 2020. - DOI: https://doi. org/10.7326/M20-2189.

11. Microbial etiology of pneumonia: Epidemiology, diagnosis and resistance patterns / C. Cilloniz, I. MartinLoeches, C. Garcia-Vidal [et al.] // Int. J. Mol. Sci. - 2016. - No. 17 (12). - P. 2120. - DOI: https://doi.org/10.3390/ ijms17122120.

12. Dandachi D. Viral pneumonia: etiologies and treatment / D. Dandachi, M. C. Rodriguez-Barradas // Journal of Investigative Medicine. - 2018. - No. 66. P. 957-965. - DOI: http://dx.doi.org/10.1136/jim-2018-000712.

этиология, эпидемиология, клиника, диагностика, лечение и профрилактика: учебно-методическое пособие] Moscow; 2020. Russian.

4. Liang T. [Handbook of COVID-19 prevention and treatment]. Zhejiang University School of Medicine. 2020;1: 68.

5. Yuen KS, Ye ZW, Fung SY, Chan CP, Jin DY. SARS-CoV-2 and COVID-19: the most important research questions. Cell Biosci. 2020;10: 40.

6. Callaway E, Cyranoski D. Why snakes probably aren't spreading the new China virus: one genetic analysis 
suggests reptilian reservoir - but researchers doubt that the coronavirus could have originated in animals other than birds or mammals. Nature. 2020 Jan. DOI: 10.1038/ d41586-020- 00180-8.

7. Zhou Fei, Yu Ting, Du Ronghui, Fan Guohui, Liu Ying, Liu Zhibo et al. Clinical course and risk factors for mortality of adult inpatients with COVID-19 in Wuhan, China: a retrospective cohort study. Lancet. 2020;395: 1054-62.

8. Morley JE, Vellas B. COVID-19 and Older Adult. J Nutr Health Aging. 2020. DOI:10.1007/s12603- 020-1349-9.

9. Pengfei Sun, Shuyan Qie, Zongjian Liu, Jizhen Ren, Kun Li, Jianing Xi. Clinical characteristics of 50466 hospitalized patients with 2019-nCoV infection. J Med Virol. 2020. DOI:10.1002/jmv.25735.
10. Joshua P. Metlay, Grant W. Waterer. Treatment of Community-Acquired Pneumonia During the Coronavirus Disease 2019 (COVID-19) Pandemic. Ideas and Opinions. 2020;7. DOI: https://doi.org/10.7326/M20-2189.

11. Cilloniz C, Martin-Loeches I, Garcia-Vidal C, San Jose A, Torres A. Microbial Etiology of Pneumonia: Epidemiology, Diagnosis and Resistance Patterns. Int J Mol Sci. 2016;17(12): 2120. DOI: https://doi.org/10.3390/ ijms17122120.

12. Dandachi D, Rodriguez-Barradas MC. Viral pneumonia: etiologies and treatment. Journal of Investigative Medicine. 2018;66: 957-65. DOI: http://dx.doi. org/10.1136/jim-2018-000712. 